Journal homepage:

http://www.bsu.edu.eg/bsujournals/JVMR.aspx

Online ISSN: 2357-0520

Print ISSN: 2357-0512

Original Research Article

\title{
Monitoring and molecular characterization of multidrug resistant enteropathogenic $E$. coli in dairy calves and their environment
}

\author{
El Bably M. A. ${ }^{1}$, Asmaa N. Mohammed ${ }^{1}$, Manar B. Mohamed ${ }^{1}$, Hanan A. Fahmy ${ }^{2}$ \\ ${ }^{1}$ Department of Hygiene, Zoonoses and Epidemiology, Faculty of veterinary Medicine, Beni-Suef University, Beni-Suef \\ 62511, Egypt. \\ ${ }^{2}$ Department of biotechnology, Animal Health research Institute, Dokki, Giza
}

\section{ABSTRACT}

This study was performed to investigate the frequency and the distribution of antimicrobial resistance and resistant genes in enteropathogenic Escherichia coli (EPEC) isolated from both calves and their environment. Fecal samples $(n=136)$ were collected from calves, besides 270 environmental samples for isolation and identification of EPEC. 50 E. coli isolates comprising 6 serogroupgs were recovered and tested against 12 antimicrobials comprising 4 different groups and 3 disinfectants with characterization of resistance genes. Results revealed that $E$. coli was isolated in the highest percentage from diarrheic calves $(68.3 \%)$ followed by apparently healthy and environment (56.7 and 56.6\%, respectively). Six serogroups of $E$. coli were identified from diarrheic calves with the highest percentage of $\mathrm{O}_{26}$ $\left(27.8 \%\right.$ ) followed by $\mathrm{O}_{159}$ and $\mathrm{O}_{55}$ (16.7 and $16.6 \%$, respectively).The tested isolates showed high rates of resistance to tetracycline, ampicillin, and sulfamethoxazole-trimethoprim whereas the highest rates of susceptibility were found to enrofloxacin and neomycin. Meanwhile the highest bactericidal effect against $E$. coli isolates from calves and environment was exhibited by Virkon ${ }^{\circledR} \mathrm{S}$ (80 \% and $70 \%$, respectively) compared to $80 \%$ and $50 \%$, respectively for $\mathrm{TH}^{4+}$ and 60 and $70 \%$, respectively for iodine. E. coli isolates were found to include the following genes bla TEM, qacED1, $d f r A$, tetA, and sull. In conclusion, the high prevalence of multidrug resistant $E$. coli provided insights about the possibility of dairy calves to act as source of resistance genes in the environment that pose health risk for humans and animals.
\end{abstract}

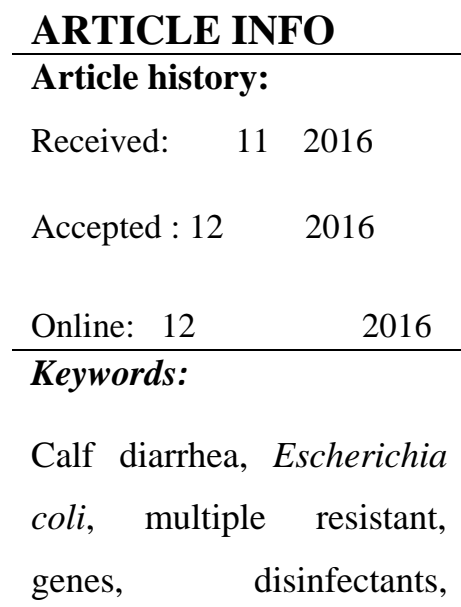
monitoring. 


\section{Introduction}

Calf diarrhea is one of the most economic and pervasive concern in veterinary industry all around the world. It constitutes substantial costs in terms of calf mortality, veterinary costs, and loss in calf value. Calf diarrhea is a disease complex characterized by acute undifferentiated diarrhea in young calves up to 3 months of age. It is a multifactorial disease, where not only the causative pathogenic agent affects its outcome but also calf age, management, and environmental factor (Bruning-Fann and Kaneene, 1992). E. coli and Salmonella are considered the most common and economically important causes of diarrhea in young calves (Muktar $e t$ al., 2015). Shigella, Klebsiella and $C$. perfringens have also been identified among the bacterial causes of calf diarrhea. The prevalence of each pathogen and the disease incidence can vary by farm location, management practices, and herd size (Acha et al., 2004).

Although E. coli is potentially pathogenic, it is a normal inhabitant of the gastrointestinal tract of worm blooded animals. E. coli can be responsible for the transfer of resistance genes that reflect the selective pressure from use of antimicrobials in treatment practices of populations (Van den Bogaard and Stobberingh, 2000). Monitoring enteric E. coli is essential as indicators for antimicrobial resistance in animal populations (Franklin et al., 2001).

Bacterial antimicrobial resistance is an emerging and serious public health concern especially in veterinary medicine, due to the possible transfer of resistance genes between animal and human strains (Martinez and Baquero, 2002). The husbandry and management practices followed in several dairy farms contribute to the high frequency of antimicrobial resistance, such as raising calves in calf barns with low level of hygiene exposing them to pathogens and disease with subsequent use of antimicrobials. Calves housed separately to control infection are fed milk or milk replacer, which may contain antibiotics. Another popular practice in the veterinary medicine is using sub-doses of antibiotics as growth promoters (Svensson et al., 2003).

In Egypt, overuse and/or abuse of antimicrobials are common in stockbreeding, which possess high risks of antimicrobial-resistance contaminations. Knowledge of used antibiotics and local antimicrobial resistance patterns are essential to guide empirical and pathogenspecific therapy and critical for optimal decisions regarding infection control policies and help assessing the magnitude of the resistance problem (Doyne et al., 2004).
The overriding purposes of this study was to monitor the frequency and distribution of multi-drug resistant strains of $E$. coli associated with calf diarrhea and their environment and some genes responsible for their resistance in a dairy herd.

\section{Materials and methods}

\subsection{Study site and animal population}

This study was carried out in a private dairy farm located in Beni-Suef district during the period from September 2014 till April 2016; it included 183 dairy cows of different production stages besides 83 calves of different ages ( 1 week to three months). Calve were housed separately from adult herd in completely sheltered yards each containing 25 calves with earthy floor. Water was provided ad libitum from common water trough. Newly born calves were separated from their dams soon after birth and receive colostrum for the first three days of age from buckets ad libitum followed by milk replacer that contain neomycin antibiotic as a growth promoter and concentrates for elderly calves. No special attention was paid for cleaning and disinfection of milk equipment or buckets. The general hygienic conditions prevailing in the farm was fair.

\subsection{Structure questionnaire}

A questionnaire was designed and used to collect data at both the individual animal and farm levels, including the following information (numbers of cows, numbers of un-weaned calves, calves age, calf management (time for cow-calf separation, feeding, use of calf group feeder and rearing systems), routines for antimicrobial treatment, number of calves with diarrhea in the herd, calf mortality.

\subsection{Study design}

A cross-sectional study was carried out to investigate the prevalence and outline the most predominant bacterial agents causing diarrhea in calves by different cultural, biochemical and serological techniques, and to test their antimicrobial sensitivity in-vitro and then characterize resistance genes in calves and their surrounding environment. Samples were collected monthly from calves and their surrounding environment using stratified sampling technique throughout the study period.

\subsection{Collection of samples}

A total number of 136 fresh fecal samples were collected directly under aseptic condition from the rectum of both apparently healthy and diarrheic calves using sterile rectal swabs that were kept in sterilized containers and preserved on ice to be transferred to the 
lab of animal hygiene in the Faculty of Veterinary Medicine, Beni-Suef University. Meanwhile, 270 environmental samples including individual milk samples, water samples, trough swabs, swabs from attendants' hands, soil samples that were collected from different sites particularly from the wetted area with high organic load and flies samples that were collected using baited jug traps (NMC, 1999; APHA, 1989; Clegg et al., 1983 and Watson et al., 1994). Samples were properly identified and immediately sent to the lab for further microbiological examination.

\subsection{Isolation and identification of $E$. coli}

All samples were diluted in phosphate buffered saline at $37^{\circ} \mathrm{C}$ for $24 \mathrm{hrs}$ for isolation of E. coli then loopful was cultured on MacConkey's agar (Oxoid; CM0115) and incubated at $37^{\circ} \mathrm{C}$ for $18-24 \mathrm{hrs}$. Lactose positive colonies were cultured on Eosin Methylene Blue (Oxoid; CM 69) and incubated at 37C for 24hrs. Metallic green colonies were selected and sub cultured on nutrient agar for identification. Gram staining technique was applied and Gram negative short bacilli were selected and the following biochemical tests were applied TSI, indol, citrate utilization, urease and methyl red tests according to Collee et al. (1996) as well as RapID® (Remel; USA) kits which were used for $E$. coli confirmation.

\subsection{Serogrouping of $E$. coli}

Forty two isolates of E. coli (16 form calves and 26 from environment) were serogrouped by slide agglutination test using standard polyvalent and monovalent E. coli antisera (Edwards and Ewing, 1972)

\subsection{In-vitro antimicrobial susceptibility testing}

The efficacy of 4 different classes of antimicrobials (tetracyclines, $\beta$ - lactamases, sulphonamides and phenicols) and 3 different disinfectants; $\mathrm{TH}^{4+} 0.5 \%$ (SoGeVal, France), Virkon®S 1\% (Antec international $\mathrm{TD}, \mathrm{UK}$ ) and iodine 5\% (Oxoid, USA) were tested against $50 \mathrm{E}$. coli isolates ( 20 from diarrheic calves and 30 from their environment).

\subsubsection{Antibiotic sensitivity testing (CLSI, 2012)}

Fifty E. coli isolates from calves and their environment were cultivated on Muller-Hinton agar under aerobic condition (at $37^{\circ} \mathrm{C}$ for $24 \mathrm{hrs}$ ) for testing their susceptibility to 12 commonly used antibiotics

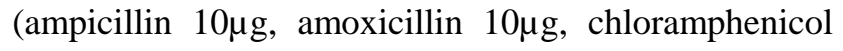
$30 \mu \mathrm{g}, \quad$ oxytetracycline $5 \mu \mathrm{g}$, sulfamethoxazole/trimethoprim $25 \mu \mathrm{g}$, tetracycline $30 \mu \mathrm{g}$, neomycin $30 \mu \mathrm{g}$, florofenicol $30 \mu \mathrm{g}$, penicillin $10 \mu \mathrm{g}$, erythromycin $15 \mu \mathrm{g}$, enrofloxacin $5 \mu \mathrm{g}$ and cefoxitin $30 \mu \mathrm{g})$.

\subsubsection{Disinfectant sensitivity testing}

The same E. coli isolates subjected to antibiotic sensitivity were screened for susceptibilities to the following disinfectant $\mathrm{TH}^{4+} 0.5 \%$ (SoGeVal, France), Virkon ${ }^{\circledR}$ S $1 \%$ (Antec international TD, UK) and iodine 5\% (Oxoid, USA) at different exposure times (5 min., 10 min., $15 \mathrm{~min}$. and $30 \mathrm{~min}$.) using broth macro dilution test Standard strain of E. coli ATCC 25922 was applied as a quality control positive organism (Costa et al., 1998).

\subsection{Detection of antimicrobial resistance genes using PCR}

PCR was applied on 6 multidrug resistant (MDR) E. coli isolates ( 3 from calves and 3 from the environment) that showed resistance to 3 or more different antimicrobial agents, for detection of following 8 resistance genes tetA(A) (responsible for resistance to tetracyclines), bla $a_{T E M}, b_{\text {S }} a_{S H}$, bla $_{O X A-1}$ (responsible for resistance to $\beta$-lactams), Sull (responsible for resistance to sulfonamides), $d f r A$ (responsible for resistance to trimethoprim), floR (responsible for resistance to phenicols), and qacED1 (responsible for resistance to quaternary ammonium compound, QAC) (Table 1).

\subsubsection{DNA extraction}

All E. coli isolates were cultured on Peptone water (at $37^{\circ} \mathrm{C}$ for $24 \mathrm{hrs}$ ). One hundred and fifty microliters of cultured PW media were added to four hundred microliters from sterile distilled water. All components were boiled for $12 \mathrm{~min}$. This suspension was frozen and then centrifuged at $14000 \mathrm{rpm}$ for $14 \mathrm{~min}$.

\subsubsection{PCR screening for antimicrobial resistance genes}

The E. coli strains were grown in $500 \mu 1 \mathrm{LB}$ broth overnight, and $20 \mu \mathrm{l}$ of the culture was transferred to 200 $\mu \mathrm{l}$ lysis buffer [0.1 M Tris- $\mathrm{HCl}(\mathrm{pH} 8.5), 0.05 \%$ Tween 20 , and $0.24 \mathrm{mg} / \mathrm{ml}$ proteinase $\mathrm{K}]$. The samples were incubated at $60 \mathrm{C}$ for 1 hour and subsequently heated at 97C for 15 min (Lanz et al., 2003). The PCR primers are compiled in Table (1). The multiplex PCRs were all performed with a total $25 \mu$ l reaction mixture and a Qiagen multiplex PCR kit (Qiagen, Shanghai) with $1 \mu \mathrm{l}$ Qiagen multiplex PCR master mixture, 1× Q-solution, and $1 \times$ primer mixture according to the manufacturer's instructions. The PCRs were performed as follows: 1 cycle of 4 min at $95^{\circ} \mathrm{C} ; 35$ cycles, each consisting of 1 min at $95^{\circ} \mathrm{C}, 1 \mathrm{~min}$ at annealing temperature, and $1 \mathrm{~min}$ at $72^{\circ} \mathrm{C}$; and 1 cycle of $7 \mathrm{~min}$ at $72^{\circ} \mathrm{C}$ list of primers used showed in Table (1). 


\subsection{Statistical analysis}

Data were recorded using the Microsoft excel spread sheet then prepared for analysis. The prevalence of diarrhea in dairy farms and frequent distribution of bacteria in both animals and environmental samples were calculated by the use of non-parametric tests (Chi-square test, $\mathrm{K}$ independent sample) using statistical package for social sciences (SPSS, version 20.0).

\section{Table 1 Oligonucleotide primers sequences of antimicrobial resistance genes in $E$. coli}

\begin{tabular}{|c|c|c|c|}
\hline Primer & Sequence & Amplified product & Reference \\
\hline \multirow[t]{2}{*}{$\operatorname{TetA}(A)$} & 5'- GGTTCACTCGAACGACGTCA-3' & $576 \mathrm{bp}$ & Randall et al. 2004 \\
\hline & 5'- CTGTCCGACAAGTTGCATGA-3' & & \\
\hline \multirow[t]{2}{*}{ Sul1 } & 5'- $C G G$ CGT GGG CTA CCT GAA CG-3' & $433 \mathrm{bp}$ & Ibekwe et al., 2011 \\
\hline & 5'- GCC GAT CGC GTG AAG TTC CG-3' & & \\
\hline \multirow[t]{2}{*}{ dfrA } & 5'- AGC ATT ACC CAA CCG AAA GT-3' & 817 bp & Huovinen et al., 1995 \\
\hline & 5'- TGT CAG CAA GAT AGC CAG AT-3' & & \\
\hline \multirow[t]{2}{*}{ floR } & 5'- TTTGGWCCGCTMTCRGAC-3' & 494 bp & Doublet et al., 2003 \\
\hline & 5'- SGAGAARAAGACGAAGAAG-3' & & \\
\hline qacED1 & $\begin{array}{c}\text { 5' }^{\prime} \text { TAA GCC CTA CACAAA TTG GGA GAT AT-3' } \\
\text { 5'- GCC TCC GCA GCG ACT TCCACG-3' }\end{array}$ & $362 \mathrm{bp}$ & $\begin{array}{c}\text { Chuanchuen } \text { et al., } \\
2007\end{array}$ \\
\hline \multirow[t]{2}{*}{ blateM } & 5'- ATCAGCAATAAACCAGC-3' & 516 bp & \multirow{6}{*}{ Colom et al., 2003} \\
\hline & 5'- CCCCGAAGAACGTTTTC-3' & & \\
\hline \multirow[t]{2}{*}{ bla $_{S H V}$} & 5'- AGGATTGACTGCCTTTTTG-3' & 392 bp & \\
\hline & 5'- ATTTGCTGATTTCGCTCG-3' & & \\
\hline \multirow[t]{2}{*}{ Blaoxa-1 } & 5'- ATATCTCTACTGTTGCATCTCC-3' & 619 bp & \\
\hline & 5'- АAACCCTTCAAACCATCC-3' & & \\
\hline
\end{tabular}

\section{Results}

\subsection{Frequency of bacterial isolates from calves}

The frequency of bacteriological isolation from fecal samples of both diarrheic and healthy calves were $45 / 49(91.8 \%)$ and $27 / 87(31.03 \%)$, respectively, and with a total prevalence of $72 / 136(52.9 \%)$. A total of 93 bacterial isolates were recovered (30 and 63 from healthy and diarrheic calves, respectively). E. coli was the most prevalent isolates from fecal samples of examined calves $(60 / 136 ; 64.5 \%)$. Moreover $E$. coli was the most prevalent isolates recovered from both diarrheic and apparently healthy calves (68.3 and 56.7\% respectively) (at X2 $=122.28, \mathrm{P}<0.0001$ ), followed by Klebsiella (16.1\%), C. perfringens (11.8\%), Shigella (4.3\%), and finally Salmonella (3.2\%) (Table 2).

\subsection{Frequency of bacterial isolates from environment \\ Out of 270 environmental samples 128 were bacteriologically positive $(47.4 \%)$ of which 150}

bacterial isolates were recovered. $E$. coli was the most prevalent isolates (68 isolates with a prevalence rate $45.3 \%$ ) followed by Klebsiella, Salmonella, Shigella and $C$. perfringens $(32.0,10.7,7.3$ and $4.6 \%$, respectively) (at $\mathrm{X} 2=487.63, \mathrm{P}<0.001$ ) (Table 3 ). Among the $68 \mathrm{E}$. coli isolates obtained from environmental samples the highest percentage was recovered from soil $(66.0 \%)$ followed by flies $(47.8 \%)$, water trough $(39.1 \%)$, attendant's hands $(38.5 \%)$ and feed manager $(30.8 \%)$, while the least percentage was recovered from milk bucket (18.8\%).

\subsection{Serogrouping of $E$. coli obtained from calves and their environment \\ Concerning serogrouping of E. coli isolates obtained from both calves and their environment, it was found that $\mathrm{O} 26$ was the most prevalent serogroup (31\%) followed by O55 (19\%), O159 (16.78\%), O111 (14.3\%) then untyped stains $(9.5 \%)$ and $\mathrm{O} 127(7.1 \%)$ and finally $\mathrm{O} 103(2.4 \%)$. Belonging the calves isolated E. coli serogroups, O26 was the most prevalent $(31.3 \%)$, followed by $\mathrm{O} 159$ and $\mathrm{O} 55$ (18.8\% for each) then $\mathrm{O} 111$}


and untyped stains (12.5\% for each) then $\mathrm{O} 103(6.3 \%)$ while $\mathrm{O} 127$ was not detected. On the other hand, among E. coli serogroups obtained from environmental samples O26 was the most frequently detected followed by O55, O111, O159, O127 and untyped $(30.8,19.2,15.4,15.4$, 11.5 and $7.7 \%$, respectively) while $\mathrm{O} 103$ was not detected (Table 4).

\section{Table 2 Frequent distribution of bacteria isolated from calves in the examined farm}

\begin{tabular}{|c|c|c|c|c|c|c|c|c|}
\hline \multirow{3}{*}{ Calves } & \multirow{3}{*}{$\begin{array}{c}\text { Total } \\
\text { examined } \\
\text { (No.) }\end{array}$} & \multirow{3}{*}{$\begin{array}{l}\text { Positive } \\
\text { isolation } \\
\text { No. }(\%)\end{array}$} & \multirow{3}{*}{$\begin{array}{c}\text { Bacteria } \\
\text { I isolates } \\
\text { (No.) }\end{array}$} & \multicolumn{5}{|c|}{ Bacterial isolates $(\%)^{*}$} \\
\hline & & & & E. coli & Salmonella & Shigella & Klebsiella & C. perfringens \\
\hline & & & & No. (\%) & No. (\%) & N. (\%) & No. (\%) & No. (\%) \\
\hline Apparently healthy & 87 & $27(31.0)$ & 30 & $17(56.7)$ & ND & ND & $5(16.7)$ & $8(26.7)$ \\
\hline Diarrheic & 49 & $45(91.8)$ & 63 & $43(68.3)$ & $3(4.8)$ & $4(6.3)$ & $10(15.9)$ & $3(4.8)$ \\
\hline Total & 136 & $72(52.9)$ & 93 & $60(64.5)$ & $3(3.2)$ & $4(4.3)$ & $15(16.1)$ & $11(11.8)$ \\
\hline$X^{2}=122.28, P<0.0001$ & ND: not & ected & $\%$ wer & ulated ac & ding to No. & the corr & ponding $b$ & erial isolates \\
\hline
\end{tabular}

\section{Table 3 Frequent distribution of bacteria isolated from calf's environment in the examined}

\section{farm}

\begin{tabular}{|c|c|c|c|c|c|c|c|c|c|}
\hline \multirow[t]{3}{*}{ Sample } & & \multirow{3}{*}{$\begin{array}{c}\text { Total } \\
\text { examined } \\
(\text { No. })\end{array}$} & \multirow{3}{*}{$\begin{array}{l}\text { Positive } \\
\text { isolation } \\
\text { No. }(\%)\end{array}$} & \multirow{3}{*}{$\begin{array}{c}\text { Bacterial } \\
\text { isolates } \\
\text { (No.) }\end{array}$} & \multicolumn{5}{|c|}{ Bacterial isolates (\%) } \\
\hline & & & & & E. coli & Salmonella & Shigella & Klebsiella & C. perfringens \\
\hline & & & & & No. $(\%)$ & No. $(\%)$ & No. (\%) & No. $(\%)$ & No. $(\%)$ \\
\hline \multirow{2}{*}{ Milk } & Sample & 30 & ND & ND & ND & ND & ND & ND & ND \\
\hline & Bucket & 30 & $17(56.7)$ & 16 & $3(18.8)$ & ND & $1(6.3)$ & $12(75.0)$ & ND \\
\hline \multirow{2}{*}{ Water } & Source & 30 & ND & ND & ND & ND & ND & ND & ND \\
\hline & Trough & 30 & $23(76.7)$ & 23 & $9(39.1)$ & ND & $1(4.3)$ & $11(47.8)$ & $2(8.7)$ \\
\hline \multirow{2}{*}{ Feed } & Sample & 30 & $2(6.7)$ & 2 & ND & $1(50.0)$ & ND & ND & $1(50.0)$ \\
\hline & Manager & 30 & $11(36.7)$ & 13 & $4(30.8)$ & $2(15.4)$ & $2(15.4)$ & $3(23.1)$ & $2(15.4)$ \\
\hline \multicolumn{2}{|c|}{ Attendants hands } & 30 & $26(86.7)$ & 26 & $9(38.5)$ & $2(11.5)$ & $1(3.8)$ & $12(46.2)$ & ND \\
\hline \multicolumn{2}{|c|}{ Flies } & 30 & $19(63.3)$ & 23 & $11(47.8)$ & $5(21.7)$ & $2(8.6)$ & $5(26.1)$ & ND \\
\hline \multicolumn{2}{|l|}{ Soil } & 30 & $30(100.0)$ & 47 & $31(66.0)$ & $5(10.6)$ & $4(8.5$ & $5(10.6)$ & $2(4.3)$ \\
\hline \multicolumn{2}{|c|}{ Total } & 270 & $128(47.4)$ & 150 & $68(45.3)$ & $16(10.7)$ & $11(7.3)$ & $48(32.0)$ & $7(4.7)$ \\
\hline \multicolumn{3}{|c|}{$X^{2}=487.63, P<0.001$} & not detected & $* \%$ wer & lculated ac & ording to No. & f the corr & ponding ba & rial isolates \\
\hline
\end{tabular}

\subsection{Antibiotic sensitivity testing}

Concerning In-vitro sensitivity of $50 \mathrm{E}$. coli isolates recovered from calves $(n=20)$ and their environment $(n=30)$ against 12 antimicrobials (Table 5). E. coli isolated from calves were highly sensitive to enorofloxacin and neomycin $(80.0 \%$ and $60.0 \%$, respectively) and they showed intermediate sensitivity towards chloramphenicol, florofenicol (70.0\% for each) and erythromycin (50\%). Complete resistances $(100.0 \%)$ were detected against the $\beta$-lactamases (ampicillin, amoxicillin, and penicillin), tetracyclines (tetracycline, oxytetracycline), cefoxitin and
sulfamethoxazole-trimethoprim.Meanwhile environmental strains of $E$. coli showed low level of sensitivity toward enrofloxacin (20\%) and chloramphenicol $(10.0 \%)$ and intermediate sensitivity to neomycin and erythromycin (50.0 and $30.0 \%$, respectively) and complete resistance $(100 \%)$ to the rest of antibiotics (at $\left.\mathrm{X}^{2}=30.66, \mathrm{P}<0.001\right)$.

\subsection{Disinfectant sensitivity testing}

Referring to the bactericidal effect of the 3 types of disinfectants at different exposure times against $E$. coli isolated from calves and their environment. E. coli isolated from calves $(n=20)$ showed the highest 
bactericidal effect after $30 \mathrm{~min}$. of exposure to both $\mathrm{TH}^{4+}$ $0.5 \%$ and Virkon ${ }^{\circledR} \mathrm{S} 1 \%$ followed by $15 \mathrm{~min}$ (70.0 and
3.6. Polymerase chain reaction for detection of antimicrobial resistance genes

\section{Table 4 Serogrouping of $E$. coli isolated from diarrheic calves and their environment}

\begin{tabular}{|c|c|c|c|c|c|c|c|c|}
\hline \multirow[t]{3}{*}{ Isolates sites } & \multirow{3}{*}{$\begin{array}{l}\text { No. of } \\
\text { tested } \\
\text { isolates }\end{array}$} & \multicolumn{7}{|c|}{ E. coli serogroups } \\
\hline & & $\mathbf{O}_{26}$ & $\mathbf{O}_{111}$ & $\mathrm{O}_{103}$ & $\mathbf{O}_{127}$ & $\mathrm{O}_{159}$ & $\mathrm{O}_{55}$ & Untyped \\
\hline & & No. (\%) & No. (\%) & No. (\%) & No. (\%) & No. (\%) & No. (\%) & No. (\%) \\
\hline Calves & 16 & $5(31.3)$ & $2(12.5)$ & $1 \quad(6.3)$ & ND & $3(18.8)$ & $3(18.8)$ & $2(12.5)$ \\
\hline Environment & 26 & $8(30.8)$ & $4(15.4)$ & ND & $3(11.5)$ & $4(15.4)$ & $5(19.2)$ & $2(7.7)$ \\
\hline Total & 42 & $13(31)$ & $6(14.3)$ & $1(2.4)$ & $3(7.1)$ & $7(16.7)$ & $8(19)$ & $4(9.5)$ \\
\hline
\end{tabular}

Table 5 In-vitro sensitivity of $E$. coli isolated from calves and their environment against different antimicrobials

\begin{tabular}{|c|c|c|c|c|c|c|}
\hline \multirow[b]{2}{*}{ Tested antibiotic $(\mu \mathrm{g})$} & \multicolumn{3}{|c|}{$\begin{array}{l}\text { Calves } E \text {. coli isolates } \\
(n=20)\end{array}$} & \multicolumn{3}{|c|}{ Environment $E$. coli isolates $(n=30)$} \\
\hline & $\mathbf{R}$ & I & $\mathbf{S}$ & $\mathbf{R}$ & I & $\mathbf{S}$ \\
\hline Enrofloxacin $\quad(10)$ & - & 20.0 & 80.0 & 60.0 & 20.0 & 20.0 \\
\hline Neomycin & - & 40.0 & 60.0 & 50.0 & 50.0 & - \\
\hline Chloramphenicol (30) & - & 70.0 & 30.0 & 40.0 & 50.0 & 10.0 \\
\hline Flroofenicol (30) & - & 70.0 & 30.0 & 100.0 & - & - \\
\hline Erythromycin (15) & 50.0 & 50.0 & - & 70.0 & 30.0 & - \\
\hline Tetracycline (30) & 100.0 & - & - & 100.0 & - & - \\
\hline Oxytetracycline (5) & 100.0 & - & - & 100.0 & - & - \\
\hline Penicillin $\quad$ (10) & 100.0 & - & - & 100.0 & - & - \\
\hline Ampicillin & 100.0 & - & - & 100.0 & - & - \\
\hline Amoxicillin & 100.0 & - & - & 100.0 & - & - \\
\hline Sulfamethoxazole/trimethoprim (25) & 100.0 & - & - & 100.0 & - & - \\
\hline Cefoxitin & 100.0 & - & - & 100.0 & - & - \\
\hline
\end{tabular}

$\mathrm{X}^{2}=30.66, \mathrm{P}<0.001 ; \mathrm{R}$ : resistant; I: intermediate; S: sensitive

$60.0 \%$, respectively) and the least activity was after 5 min. of exposure (40\%). Meanwhile iodine 5\% showed the highest bactericidal activity after $30 \mathrm{~min}$. $(60.0 \%)$ and the least was after $5 \mathrm{~min}$. (20.0\%). On the other hand environmental strains $(n=30)$ showed the highest sensitivity to Virkon ${ }^{\circledR} \mathrm{S} 1 \%$ after contact time 30 and $15 \mathrm{~min}$ (70.0 and 50\%, respectively), followed by iodine $5 \%$ after 30 and 15 min contact time (70.0 and $40.0 \%$, respectively); while the least bactericidal activity was exhibited by $\mathrm{TH}^{4+} 0.5 \%$ after 30 and $15 \mathrm{~min}$ contact time $\left(50 \%\right.$ for each) $\left(\right.$ at $\left.\mathrm{X}^{2}=17.79, \mathrm{P}<0.001\right)$ (Table 6).
The results of PCR of MDR E. coli isolates recovered from calves and environment revealed that bla $a_{T E M}$ gene was the most prevalent found in all isolates (100\%) followed by qacEDl found in 5 isolates (83.3\%); 3 from calves and 2 from environment, and $d f r A$ genes which was found in 4 isolates $(66.7 \%) ; 2$ from both calves and environment, then tetA and sull which were detected in 3 isolates ( $50 \%$ for each); both have 2 from calves and 1 from environment. Then, bla $_{S H V}$ found in 2(33.3\%); one from both calves and environment, while both bla OXA-I and floR genes were found in $1(16.7 \%)$ from calves (Table 7 and Fig. 1, 2, 3 and 4$)$. 
Table 6 In-vitro sensitivity of $E$. coli isolated from calves and their environment against three types of disinfectants at different exposure times

\begin{tabular}{|c|c|c|c|c|c|c|c|c|}
\hline \multirow{2}{*}{$\begin{array}{l}\text { Contact time } \\
\text { Disinfectants }\end{array}$} & \multicolumn{4}{|c|}{ Calves $E$. coli isolates $(n=20)$} & \multicolumn{4}{|c|}{ Environment $E$. coli isolates $(n=30)$} \\
\hline & $5 \mathrm{~min}$ & 10min & 15min & 30min & $5 \mathrm{~min}$ & 10min & $15 \mathrm{~min}$ & 30min \\
\hline $\mathrm{TH}^{4+}(0.5 \%)$ & 40.0 & 60.0 & 70.0 & 80.0 & $\mathrm{R}$ & 30.0 & 50.0 & 50.0 \\
\hline Virkon® S (1\%) & 40.0 & 50.0 & 60.0 & 80.0 & 20.0 & 40.0 & 50.0 & 70.0 \\
\hline Iodine $(5 \%)$ & 20.0 & 40.0 & 50.0 & 60.0 & $\mathrm{R}$ & 20.0 & 40.0 & 70.0 \\
\hline
\end{tabular}

$\mathrm{X}^{2}=17.79, \mathrm{P}<0.001 ; \mathrm{R}:$ resistant

\section{Table 7 Prevalence of resistance-associated genes among the examined $E$. coli.}

\begin{tabular}{|c|c|c|}
\hline \multicolumn{3}{|c|}{$E$. coli isolates $(n=6)$} \\
\hline \multirow[t]{2}{*}{ Tested gene } & \multicolumn{2}{|c|}{ Positive } \\
\hline & No. & $\%$ \\
\hline tetA & 3 & 50 \\
\hline blaTEM & 6 & 100 \\
\hline blashV & 2 & 33.3 \\
\hline blaoxA-1 & $\mathbf{1}$ & 16.7 \\
\hline sul1 & 3 & $\mathbf{5 0}$ \\
\hline dfrA & 4 & 66.7 \\
\hline floR & 1 & 16.7 \\
\hline qacED1 & 5 & 83.3 \\
\hline
\end{tabular}

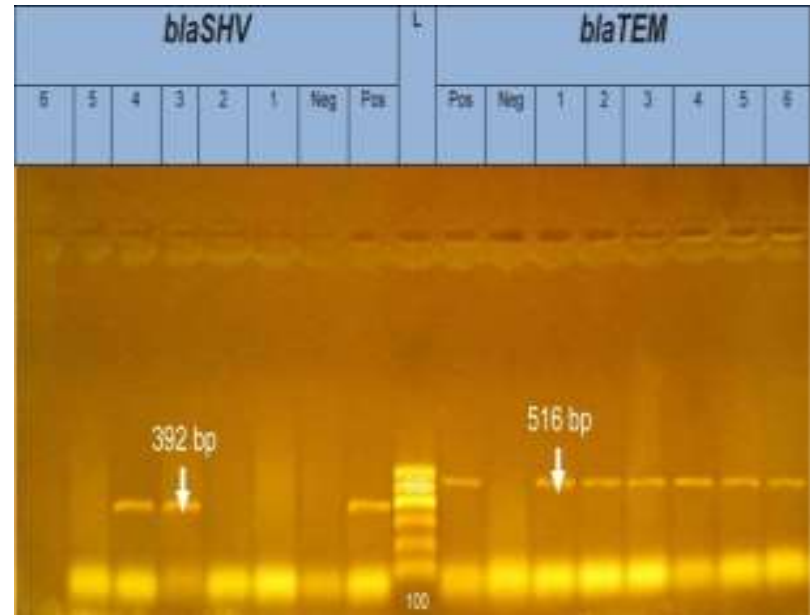

Fig. 1 PCR amplification of the 392 and 516 bp fragments of blasHV and blatEM genes, respectively from 6 E. coli (lane 1-6), Pos (control positive), Neg (control negative) L: DNA Ladder.

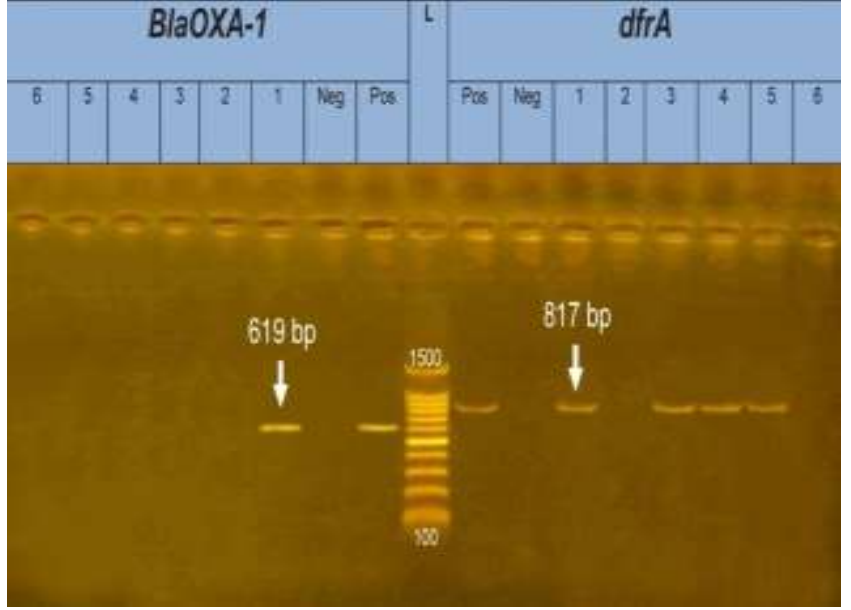

Fig. 2 PCR amplification of the 619 and $817 \mathrm{bp}$ fragments of BlaoxA-1 and $d f r A$ genes, respectively from 6 E. coli (lane 16), Pos (control positive), Neg (control negative) L: DNA Ladder. 


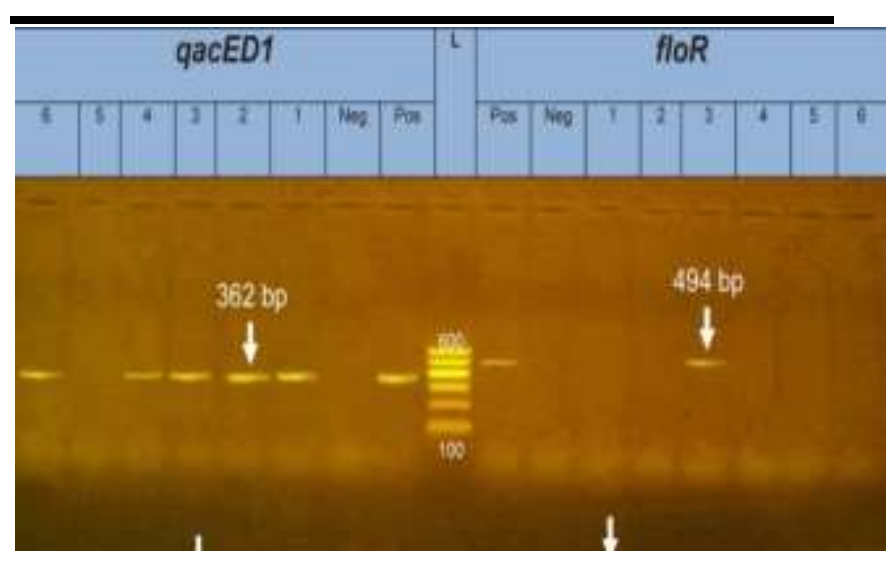

Fig. 3 PCR amplification of the 362 and 494 bp fragments of qacED1 and floR genes, respectively from $6 \mathrm{E}$. coli (lane 1-6), Pos (control positive), Neg (control negative) L: DNA Ladder.

\section{Discussion}

Calf diarrhea remains the most important cause of morbidity and mortality in young calves especially in their early life (Constable, 2004). Among the bacterial enteropathogens causing calf diarrhea is enteropathogenic E. coli (EPEC) that is considered the most economically important pathogen (Acha et al., 2004).

In the present study, a high frequency was obvious of bacterial isolates that were obtained from fecal samples of both apparently healthy and diarrheic calves. These results might be attributed to low level of hygiene prevailing in the farm where the study was applied in and no routine cleaning or disinfection to milk utensils or equipment used for feeding and drinking the calves which favor the growth of such bacteria causing diarrhea. These obtained results are in harmony with that detected by Atawa et al., (2012) who demonstrated that the positive fecal samples for bacteriological isolates were $(79.5 \%)$. Herrera-Luna et al., (2009) recorded that the frequency and percentage of bacteriologically positive samples were above $100.0 \%$ due to concurrent infection with different microorganisms whereas $E$. coli followed by $C$. perfringens, Klebsiella spp. and Proteus spp. were isolated at $(18.9,10.0,3.3,1.1 \%$, respectively). Concerning, the distribution of bacterial isolates revealed that the most predominant diarrhea

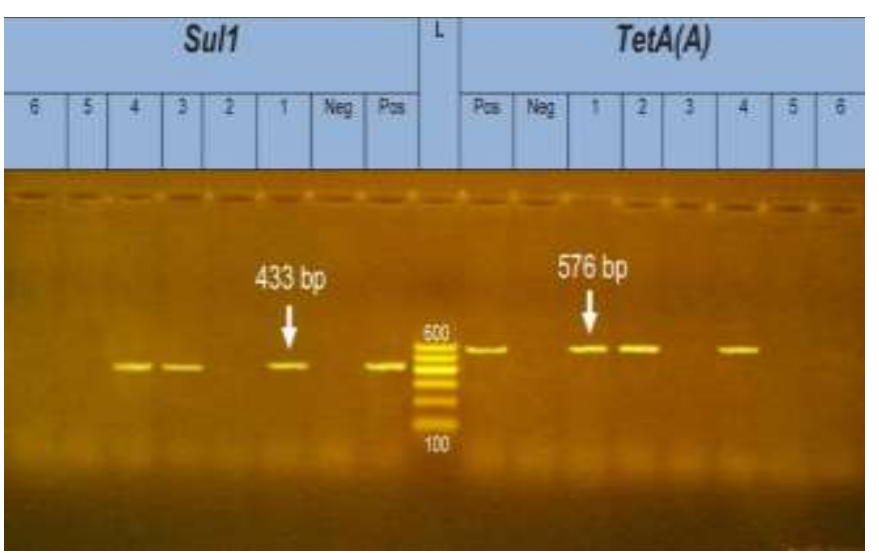

Fig. 4 PCR amplification of the 433 and 576 bp fragments of sul1 and TetA(A)genes, respectively from 6 E. coli (lane 1-6), Pos (control positive), Neg (control negative) L: DNA Ladder.

causing bacteria in calves was E. coli $(68.3 \%)$ in the examined farm. These are in coincide with that obtained by China et al., (1998) and Harbby, (2002) who found out that $E$. coli was the most predominant bacteria isolated from diarrheic calves. Furthermore, Raihan et al., (2014) who found out that frequency distribution of bacterial isolates from diarrheic calves included two types of bacteria E. coli (28\%) and Salmonella (8.8\%). El-Hamamy et al., (1999) demonstrated that the predominant isolates from diarrheic calves were $E$. coli $(52.5 \%)$, Enterobacter aerogense (15\%), proteus vulgoris (12.5\%) and Salmonella spp. (5\%). On the contrary Haschek et al., (2006) found out that the most frequently isolated pathogen from diarrheic calves was bovine coronavirus $(25.7 \%)$ while E. coli was the second highest frequent isolated enteropathogen with (17\%).

In calves' environment, the frequent distribution of enteropathogenic bacteria and their sero-grouping revealed that $E$. coli was the predominant isolated bacterial pathogen beside $E$. coli $\mathrm{O}_{26}$ was the most frequently detected serogroup which might be contributed to contamination of the calves' environment with feces which contain $E$. coli predominantly as well as the large herd size that is accompanied with high stocking density with subsequent lower degree of hygiene and less time for individual calf care, these results were to some extent coincides with that obtained by Aragan, (2012) and Hessain, (2012) who highlighted that the poor hygienic conditions of the water source 
used play a role in transmission pathogenic bacteriainduced mastitis, enteritis, and calf diarrhea, and Emmanuel et al., (2011) who isolated Proteus spp., Pseudomonas spp., Bacillus spp., E. coli, Salmonella spp. and Shigella spp. (70.21, 59.13, 58.33, 58.37, 47.02 and $21.63 \%$, respectively) from soil at dumpsites in the farm, and to some extent with Mohammed, (2016) who found that E. coli $(56.7 \%)$ followed by Salmonella spp. (26.7\%), Streptococcus faecalis (23.3\%), Shigella flexneri (16.7\%), Proteus spp. (16.7\%), and Klebsiella pneumonae $(10.0 \%)$ were the most isolated bacteria from surface water. On contrary, Minj and Behera, (2012) isolated E. coli. Salmonella sp., Shigella sp. Klebsiella sp. and Pseudomonas sp. from milk samples suggesting the possible contamination of the udder of adult cows from their surrounding environment. Also Plews et al., (1981) isolated Klebsiella and Enterobacter sp. from soil samples from calves' environment beside $E$. coli and in the same time $E$. coli couldn't be isolated from clean soil which suggests that calves are the source of soil contamination with bacterial enteropathogens. Meanwhile, Vicente et al. (2005) pointed out that water is an important source of STEC (Shiga toxin producing E. coli) in the farm and he isolated E. coli $\mathrm{O}_{113}(1.9 \%)$ from the drinking water. Mohammed et al., (2016) declared that E. coli serotypes $\mathrm{O}_{91}(41.17 \%), \mathrm{O}_{145}$ $(29.41 \%)$, and untyped (poly I-III) $(29.41 \%$ each) were the most predominant serogroups obtained from flies in cattle farms. Rahn et al., (1997) isolated E. coli $\mathrm{O}_{119}$ from calf manager together with high rates from $E$. coli $\mathrm{O}_{157}$ was also detected in calf managers and water bowels suggesting the potential transmission of infection from animal to animal. Concerning, E. coli serogroups isolated from soil samples in this study including E. coli $\mathrm{O}_{26}, \mathrm{O}_{111}, \mathrm{O}_{127}$ and $\mathrm{O}_{55}$. And Plews et al., (1981) isolated E. coli $\mathrm{O}_{26}, \mathrm{O}_{55}, \mathrm{O}_{111}, \mathrm{O}_{119}, \mathrm{O}_{124}, \mathrm{O}_{125}$ and $\mathrm{O}_{128}$ serogroups from soil sample which are similar to those isolated from calves indicating that contaminated soil may act as a source of infection to the healthy calves if being raised on.

Concerning serogroups recovered from fecal samples of diarrheic calves illustrated in Table (4) it was found that E. coli $\mathrm{O}_{26}$ was the most prevalent serogroup isolated from fecal samples of diarrheic calves and this is similar to that detected by Badouei et al., (2010) who isolated $\mathrm{O}_{157}, \mathrm{O}_{111}$ and $\mathrm{O}_{26}$ serogroups from diarrheic and nondiarrheic calves and the most common serogroup detected was $\mathrm{O}_{26}(18.4 \%)$. Similarly, Lee et al., (2008) isolated $\mathrm{O}_{26}$ and $\mathrm{O}_{111}$ from diarrheic and healthy calves (14.4\% and $12.5 \%$, respectively) suggesting that $\mathrm{O}_{26}$ and $\mathrm{O}_{111}$ consider the main cause of diarrhea in calves. Also Atawa et al., (2012) who serogrouped E. coli isolated from diarrheic calves as $\mathrm{O}_{157}, \mathrm{O}_{111}, \mathrm{O}_{125}, \mathrm{O}_{119}, \mathrm{O}_{26}$ and $\mathrm{O}_{128}$ and untyped (17.9, 9.5, 11.6, 15.8, 12.6, 8.4 and $3.2 \%$ respectively). Also, Thin et al., (2011) isolated different serogroups of $\mathrm{E}$. coli and the most predominant serogroups were O15, O20, O103 and O157 in Vietnam. Antimicrobial sensitivity tests showed that E. coli isolated from both calves and their environment showed high sensitivity to enrofloxacin and neomycin, intermediate sensitivity to chloramphenicol and florophenicol; and complete resistance to $\beta$-lactams, tetracycline and sulphamethoxazole-trimethoprime. These obtained results agreed to some extent with AbdElrahman, (2011) who recorded that E. coli isolates from calves were mostly sensitive to marbofloxacin followed by enrofloxacin (96.07 and 88.23\%, respectively), and mostly resistant to penicillin, neomycin, erythromycin, streptomycin, tetracycline and chloramphenicol. Sadiek and Sohair, (1999), El-Gaml et al. (2001) and Aba-Alkhalil and El-Naenaeey, (2003) all indicated that enrofloxacin and ciprofloxacin were the most efficient antibiotics in treatment of calf diarrhea. Also, Adetunji and Isola, (2011) indicated that E. coli isolated were resistant to nitrofuration, tetracycline, ampicillin, gentamicin, ciprofloxacin and chloramphenicol, and Mohammed et al., (2016) revealed that the antimicrobial resistance pattern of Gram-negative bacteria proved that E. coli was resistant to tetracycline $(92.9 \%)$. On the contrary EL-Seedy et al., (2016) reported that E. coli isolates were sensitive to marbofloxacin, spectinomycin and neomycin only and resistant to the majority of tested antibiotics in Egypt.

Referring to the efficiency of 3 different types of disinfectants against $E$. coli isolated from both calves and the environment, it was revealed that $\mathrm{TH}^{4+} 0.5 \%$ and Virkon ${ }^{\circledR} \mathrm{S} 1 \%$ were the most efficient disinfectants at exposure time $30 \mathrm{~min}$, while iodine $5 \%$ was the least efficient disinfectant at the same exposure time. The 
more the contact time increase the more the efficiency of the disinfectant will increase. These findings were in harmony with those found by Fawzia et al., (2013) that found $E$. coli isolates were sensitive to $\mathrm{TH}^{4+} 0.2 \%$ and Virkon s $1 \%$ using disc diffusion method (86.7\%) while by pits method $(93.3 \%)$ at the same time iodine proved to have lower efficiency which might be attributed to its need to long contact time. Gehan et al., (2009) recorded that $\mathrm{TH}^{4+}$ is the most powerful disinfectant due to synergism between QAC and glutaraldehyde. In contrast to the present data Gasparini et al., (1995) found that Virkon ${ }^{\circledR} \mathrm{S}$ was effective against Pseudomonas aeruginosa and $E$. coli and they were resistant to QAC while Saha et al., (2009) found that iodine showed moderate efficiency against $S$. aureus and $E$. coli than Klebsiella sp. S. typhi while $S$ dysenteriae was the only sensitive microorganism to iodine, reciprocally Mohammed, (2014) who indicated that iodine $0.5 \%$ had the lowest lethal effect $(0.0 \%)$ against all the isolated bacteria after 15 seconds exposure time and it's efficiency increased to be moderate when exposure time increased to $5 \mathrm{~min}$ against $E$. coli isolates with (50\%) efficiency.

Results concerning the distribution of resistance genes in $E$. coli isolates showed that all of eight's targeted resistance genes (tetA(A), dfrA, sull, floR, bla TEM, $_{\text {, }}$ bla $_{S H V}$, bla $_{O X A-l}$ and qacEDl) were detected in all of $E$. coli from calves and their environment and this is similar to that detected by Nelson et al., (2014) who detected sul1 and tet(A) genes in $73.0 \%$ E. coli isolates obtained from diarrheic calves and Momtaz et al., (2013) who detected sull and tet(A) genes in $82.78 \%$ and $51.63 \%$, respectively. Kucken et al., (2000) reported that qacED gene that is responsible for resistance to QAC was detected in $10.0 \%$ of $E$. coli isolates which is unlike the present finding where this gene was detected in 83.3\% of the tested isolates. Also Zou et al., (2014) reported that qac-EDI was detected in $7.0 \%$ of $E$. coli isolates. For $\beta$-lactams resistance genes (bla $a_{T E M}, b l a_{S H V}$ and bla ${ }_{\text {OXA }}$ ) the current results were to some extent similar to Jiang and Zhang, (2013) who reported that TEM gene was identified in $84.6 \%$ of tested isolates while $S H V$ and $O X A$ were not detected $0 \%$ of the tested isolates while floR gene that was indicated in 20 isolates which is responsible for cross resistance to florphenicol and chloramphenicol which is banded antibiotic but yet resistance to it still detected that indicates unauthorized and miss use.

\section{Conclusion}

Calves can act as a source of contamination to the environment with multiple antimicrobial resistant E. coli which poses high risk for human and animal populations. Regular screening of antibiotics sensitivity before actual application on animals is essential to reduce the possibility of dissemination of resistance genes.

\section{References}

Aba-Alkhalil and El-Naenaeey, E.Y. (2003). Evaluation of antimicrobial action of ceftifour sodium (Excenel), in vitro and vivo. Suez Canal Vet. Med. J. VI (2): 42-51.

Abd-Elrahman, A.H. (2011). Colibacillosis in newly born buffalo calves and role of Lacteal Fort in preventing recurrence of calf diarrhea. Life Sci. J. 8(4): 497-502.

Acha, S.J., Kuhn, I., Jonsson, P., Mbazima, G., Katouli, M. and Mollby, R. (2004). Studies on Calf Diarrhea in Mozambique: Prevalence of bacterial Pathogens. Acta. Vet. Scand. 45, 27-36.

Adetunji, V.O. and Isola, T.O. (2011). Antibiotic resistance of Escherichia coli, Listeria and Salmonella isolates from retail meat tables in Ibadan municipal abattoir, Nigeria. African J. Biotech. 10(30): 5795-5799.

APHA (American Public Health Association) (1989). Standard methods for the examination of water and waste water. $17^{\text {th }}$ Ed. A.P.H.A: Washington, pp.7076.

Aragan, A.K.A. (2012). Epidemiological survey on environmental bacterial pathogen causing mastitis in cattle. (M.V.Sc.) Thesis, (Animal Hygiene) Fac. Vet. Med. Alex., University.

Atawa, E.I., Sharaf, E.M. and Zakary, E.M. (2012). Bacterial diarrhea in newly born calves in Menoufiea governorate. Assiut Vet. Med. J. 58(135): 126- 137.

Badouei, M.A., Salehi, T.Z., Khorasgani, M.R., Tadjbakhsh, H., Brujeni, G.N. and Nadalian, M.G. (2010). Virulence gene profiles and intimin subtypes of Shiga toxin-producing Escherichia coli isolated from healthy and diarrheic calves. Vet. Rec. 167(22): 858-861. 
Bruning-Fann C. and Kaneene J.B. (1992). Environmental and management risk factors associated with morbidity and mortality in perinatal and pre-weaning calves: a review from an epidemiological perspective. Vet. Bull. 62: 399-413.

China, B., Pirson, V. and Mainil, J. (1998). Prevalence and molecular typing of attaching and effacing Escherichia coli among calf populations in Belgium. Vet. Microbiol. 63: 249-259.

Chuanchuen, R., Khemtong, S. and Padungtod, P. (2007). Occurrence Of Qace/Qace $\Delta 1$ Genes And Their Correlation With Class 1 Integrons In Salmonella Enterica Isolates From Poultry And Swine. Southeast Asian J. Trop. Med. Public Health. 38: 855-862.

Clegg, F.G., Chiejina, S.N., Duncan, A.L., Kay, R.N. and Wary, C. (1983). Outbreak of Salmonella Newport infection in dairy herds and their relation to management and contamination of environment. Vet. Res. 25: 112-119.

CLSI (Clinical and Laboratory Standards Institute) (2012). Performance Standards for Antimicrobial Susceptibility Testing; Twenty- Second Informational Supplement. M100-S22. Vol.32.No. 3.

Collee JG, Fraser AG, Marmion BP, Simmons A. (1996): Practical Medical Microbiology. $14^{\text {th }}$ ed.

Colom, K., Pèrez, J., Alonso, R., Fernández-Aranguiz, A., Lariňo, E. and Cisterna, R. (2003). Simple and reliable multiplex PCR assay for detection of blaTEM,blaSHV and blaOXA-1 genes in Enterobacteriaceae. FEMS Microbiology Letters. 223: $147-151$.

Constable, P.D. (2004). Antimicrobial use in the treatment of calf diarrhea. J. Vet. Int. Med. 18: 8-17.

Costa, E.O., Ribeiros, A.R., Watanabe, E.T., Garino, JR F., Silva, J.A.B. and Thiers, F.O. (1998). Avaliação in vitro dos desinfetantes utilizados na pós-ordenha (teat dipping) para controle da mastite bovina [In vitro evaluation of disinfectants used in post-dipping (teat dipping) for control of bovine mastitis]. Revta. Napgama. 1: 18-22.

Doublet, B., Lailler, R., Meunier, D., Brisabois, A., Boyd, D., Mulvey, M.R., Chaslus-Dancla, E. and Cloeckaert, A. (2003). Variant Salmonella Genomic Island 1 Antibiotic Resistance Gene Cluster in Salmonella enteric Serovar Albany. Emerging Infectious Diseases. 5(9): 585-591.

Doyne, E.O., Alfaro, M.P. and Siegel, R.M. (2004). A randomized controlled trial to change antibiotic prescribing patterns in a community. Arch. Pediatr. Adolesc. Med. 158(5): 577- 583.
Edwards, P.R., Ewing, W.H. (1972). Identification of enterobacteriaceae. $3^{\text {rd }}$ Ed. Minnea Palis, Burgess.

El - Seedy, F.R.,Abed, A.H., Yanni, H. A. and Abd El - Rahman, S.A. (2016). Prevalence of Salmonella and $E$. coli in neonatal diarrheic calves. Beni-Suef U. J. Basic and Applied Sci. 5: 45-51.

El-Gaml, A.M., Hashem, M.E. and Hatab, M. (2001).

Diarrhea in kids attributed to enterobacteria and

cryptosporidium. Assiut Vet. Med. J. 45(89): 132-141.

El-Hamamy, M.M., El-Boushi, M.E. and Fataih, H.A. (1999). Some studies on newly born calves with relationship to their immune status. SCVM. 11(2): 289.

Emmanuel, I., Joseph, N., Kingsley, E., Egbebor, E.M. and Lawrence, E. (2011). Antibiotic susceptibility profile of enteric bacterial isolates from dumpsites utisols and water sources in a rural community in cross river state, Southern Nigeria. Nature and Science. 9(5): 46-50.

Fawzia, M.A.A., Hider, M.H.A. and Saa'd, M.S.A. (2013). In-vitro evaluation by Disc-diffusion and Pits methods of antimicrobial efficiency of disinfectants used in four broiler chicken hatcheries in Babil city/ Iraq. Academic Research International. 6(4): 562- 579.

Franklin, A., Acar, J., Anthony, F., Gupt, R., Nicholls, T., Tamura, Y., Thompson, S., Threlfal, E.J., Vose, D., Van Vuuren, M., Whit, D.G., Wegener, H.C. and Costarrica, M.L. (2001). Antimicrobial resistance: harmonisation of national antimicrobial resistance monitoring and surveillance programmes in animals and in animal-derived food. Rev. Sci. Tech. 20: 859870.

Gasparini, R., Pozzi, T. and Magnelli, R. (1995). Evaluation of in vitro efficacy of the disinfectant Virkon. European Journal of Epidemology 11: 193197.

Gehan, M. Z., Anwer, W., Amer, H.M., EL-Sabagh, I.M., Rezk, A. and Badawy, E.M. (2009). In vitro efficacy comparisons of disinfectants used in the commercial poultry farms. International Journal of Poultry Science. 8: 237-241.

Harbby, H.A. (2002). Bacterial causes of diarrhea in small animals. (Kids, lambs and calves) in Sultanate of Oman. J. Egypt. Vet. Med. Ass. 62 (3): 227-235.

Haschek, B., Klein, D., Benetka, V., Herrera, C., Sommer feld-Stur, I., Vilcek, S.,Moestl, K. and 
Baumgartner, W. (2006). Detection of bovine torovirus in neonatal calf diarrhea in lower Austria and Styria (Austria). J. Vet. Med. B 53: 160-165.

Herrera-Luna, C.H., Klein, D., Lapan, G., RevillaFernanded, S., Haschek, B., Sommerfeld-Stur, I., Moestl, K. and Baumgartner, W. (2009). Characterization of virulence factors in Escherichia coli isolated from diarrheic and healthy calves in Austria shedding various enteropathogenic agents. Veterinarni Medicina. 54(1): 1-11.

Hessain, M. (2012). Epidemiological studies on mastitis in some dairy farms with special reference to its hygienic control. (M.V. Sc.) Thesis, (Animal Hygiene) Fac. Vet. Med. Mansura University.

Huovinen, P., Sundström, L., Swedberg, G. and Sköld, O. (1995). Trimethoprim and sulfonamide resistance. Antimicrobial Agents and Chemotherapy. 39: 279-289.

Ibekwe, A.M., Murinda, S.E. and Graves, A.K. (2011). Genetic Diversity and Antimicrobial Resistance of Escherichia coli from Human and Animal Sources Uncovers Multiple Resistances from Human Sources. PLoS ONE. 6 (6): 208-219.

Jiang, Y. and Zhang, X. (2013). Rsistance pattern and detection of resistance genes in Escherichia coli isolated from diarrheic calves in northeastern China. African. J. Microbiology Research. 7(5): 389-397.

Kucken, D., Feucht, H. and Kaulfer, P. (2000). Association of qacE and qacE $\Delta 1$ with multiple resistance to antibiotics and antiseptics in clinical isolates of Gram-negative bacteria. FEMS Microbiol Lett. 183: 95-98.

Lanz, R., Kuhnert, P. and Boerlin, P. (2003). Antimicrobial resistance and resistance gene determinants in clinical Escherichia coli from different animal species in Switzerland. Vet. Microbiol. 91: 73-84.

Lee,J.H., Hur, J., and Stein,B.D. (2008). Occurrence and characteristics of enterohemorrhagic E. coli $\mathrm{O} 26$ and O111 in calves associated with diarrhea. Vet. J. 176(2):205-209.

Martinez, J.L. and Baquero, F. (2002). Interactions among strategies associated with bacterial infection: pathogenicity, epidemicity and antibiotic resistance. Clin. Microbiol. Rev. 15: 647-679.

Minj, A.K. and Behera, N. (2012). Comparative microbiological quality assessment of rural and urban milk samples. Afr. J. Food Sci. 6(21): 519523.

Mohammed, A.N. (2014). Assessing the antimicrobial resistance patterns and in vitro efficacy of three disinfectants as teat dip against iodine (0.5\%) resistant mastitogenic pathogens. International Journal of Advanced Research. 2 (12): 946-953.

Mohammed, A.N. (2016). Field study on evaluation of the efficacy and usability of two disinfectants for drinking water treatment at small cattle breeders and dairy cattle farms. Environ. Monit. Assess. DOI 10.1007/s 10661-016-5147-0.

Mohammed, N.M., Abdel-Latef, G.K., Abdel-Azeem, N.M. and El-Dakhly, K. M., 2016. Ecological study on antimicrobial-resistant zoonotic bacteria transmitted by flies in cattle farms. Parasitol Res. DOI 10.1007/s00436-016-5154-

Momtaz, H., Dehkordi, F. S., Hosseini, M. J., Sarshar, M. and Heidari M. (2013). Serogroups, virulence genes and antibiotic resistance in Shiga toxinproducing Escherichia coli isolated from diarrheic and non-diarrheic pediatric patients in Iran. Gut Pathogens, 5: 39.

Muktar, Y., Mamo, G., Tesfaye, B. and Belina, D. (2015). A review on major bacterial causes of calf diarrhea and its diagnostic method. Journal of Veterinary Medicine and Animal Health. 7(5): 173185.

Nelson, J., Abdlelaziz, A., Elbanna, T., Nagiub, H. and Abdel Ghani, S. (2014). Mechanisms of Resistance to Antibiotics in Escherichia Coli from Patients with Urinary Tract Infections in Egypt. J. Am. Sci. 10 (10): 235-239.

NMC (National Mastitis Council) (1999). Laboratory handbook on bovine mastitis, revised Ed. Madison, Wisconsin. National Mastitis Council, Inc., 1-30.

Plews, P.I., Schipper, I.A., Bromel, M.C. (1981). The microbial environment of the calf with diarrhea. http://hdl.handle.net/10365/4428

Rahn, K., Renwick, S.A., Johnson, R.P., Wilson, J.B., Clarke, R.C.,Alves, D., McEwen, S., Lior, H. and Spika, J. (1997). Persistence of Escherichia coli O157:H7 in dairy cattle and the dairy farm environment. Epidemiol. Infect., 119: 251-259.

Raihan, A., Ansari, I.H., Rhaman, M.M., Islam, M.Z., Das, B.C., Habib, A., Belal, S.M. and Islam, K. (2014). Prevalence and antimicrobial resistance profile of Escherichia coli and Salmonella isolated from diarrheic calves. J. Anim. Health Prod. 2(1): $12-15$.

Randall, L.P., Cooles, S.W., Osborn, M.K., Piddock, L.J.V. and Woodward, M.J. (2004). Antibiotic resistance genes, integrons and multiple antibiotic resistance in thirty-five serotypes of Salmonella enterica isolated from humans and animals in the UK. Journal of Antimicrobial Chemotherapy. 53: 208-216. 
Sadiek, A. and Sohair, Z.H. (1999). Acute enteritis in neonatal calves in Sohag governorate with special reference to aetiology, clinico-chemical aspects and therapy. Assuit Vet. Med. J. 42(83): 200-212.

Saha, A.K., Haque, M.F., Karmaker, S. and Mohanta, M.K. (2009). Antibacterial effects of some antiseptics and disinfectants. J. Life Earth Sci. 3(4): $19-21$.

Svensson, C., Lundborg, K., Emanuelson, U. and Olsson, S.O. (2003). Morbidity in Swedish dairy calves from birth to 90 days of age and individual calf-level risk factors for infectious diseases. Prev. Vet. Med. 58: 179-197.

Thin, T.V., Hung, V.K. and Tn, D.N. (2011). Virulence factors in Escherichia coli isolated from calves with diarrhea in Vietnam. J. Vet. Sci. 12: 159-164.

Van den Bogaard, A.E. and Stobberingh, E.E. (2000). Epidemiology of resistance to antibiotic Links between animals and humans. Int. J. Antimicrob. Agents.14: 327-335.

Vicente, H.I.G., Amaral, L.A. and Cerqueira, A.M.F. (2005). Shigatoxigenic Escherichia coli serogroups O157, O111 and O113 in feces, water and milk samples from dairy farms. Braz. J. Microbiol. 36: 217-222.

Watson, D.W., Waldron, J.K. and Rutz, D.A. (1994). Integrated management of flies in and around dairy \&livestock barns. Department of entomology, New York state IPM program. Cornell University. DMFS450.000.

Zou, L., Meng, J., McDermott, P. F., Wang, F., Yang, Q., Cao, G., Hoffmann, M. and Zhao, S. (2014). Presence of disinfectant resistance genes in Escherichia coli isolated from retail meats in the USA. J. Antimicrob. Chemother. 69(10): 26442649. 